\title{
Penggunaan Metode Waterfall Dalam Rancang Bangun Sistem Informasi Penjualan
}

\author{
Nur Hidayati \\ Sistem Informasi, Universitas Bina Sarana Informatika \\ E-mail:nur.nrh@bsi.ac.id
}

\begin{abstract}
Abstrak-Using Waterfall Method in Sales Information System Architecture. Bidang usaha penjualan memang sangat menarik untuk ditekuni, bukan hanya perusahaan atau organisasi, tapi masyarakat luas juga berusaha keras mengembangkan usahanya didalam bidang ini. Akan tetapi usaha keras mereka didalam meningkatkan penjualannya tidak diimbangi dengan penggunaan sistem informasi yang baik, sehingga dapat menimbulkan permasalahan. Permasalahan tersebut muncul karena organisasi ataupun perusahaan masih menggunakan sistem konvensional seperti dalampemesanan barang, pengolahan data, penyimpanan data dan pembuatan laporan penjualannya. Hal tersebut mengakibatkan terjadinya kesalahan pencatatan data, pencarian data terlalu lama dan keterlambatan dalam pembuatan laporan serta data yang dihasilkan tidak akurat. Salah satu contoh pembahasan disini adalah Toko Fadhil Genteng Bogor, karena Toko ini memiliki usaha penjualan yang perkembangannya bagus dan sangat membutuhkan sekali adanya sistem informasi yang terkomputerisasi sehingga dapat memberikan pelayanan yang memuaskan bagi pelanggannya, membutuhkan pengolahan data yang baik sehingga menghasilkan informasi yang akurat. Oleh karena itu, diperlukan adanya rancang bangun sistem informasi penjualan untuk dapat diterapkan di Toko tersebut, dengan menggunakan Netbeans dandatabase MySQL. Metode yang digunakan dalam rancang bangun sistem ini menggunakanWaterfall.Dengan penggunaan metode ini, maka akan lebih mempermudah dalam pembuatan rancang bangun sistem penjualan terutama pada Toko Fadhil Genteng Bogor, sehingga permasalahan yang dihadapinya dapat teratasi.
\end{abstract}

Kata Kunci—komputerisasi, penjualan, rancang, sistem,uml, waterfall

Abstract - Using Waterfall Method in Sales Information System Architecture. Field sales effort is indeed very interesting to the intense, not just a company or organization, but the wider community also strive to develop its business in this field. But their hard efforts in increasing sales is not offset by the use of a good information system, so that it can cause problems. These problems arise because the organization or company is still using conventional systems as in the reservation goods, data processing, data storage and reporting their sales. This resulted in the occurrence of error logging data, search data for too long and the delay in reporting as well as the resulting data is not accurate. One example of the discussion here are Fadhil GentengBogor Store, since this store has great sales development efforts and urgently needs once the existence of a computerized information system so as to provide services satisfactory for its customers, need a good data processing to produce accurate information. Therefore, it is necessary the presence of the sales information system architecture to be applied in the store, using Netbeans and MySQL database. The methods used in the architecture of these systems use a Waterfall. With the use of this method, it will be more ease in making sales systems architecture especially on Fadhil Genteng Bogor Store so that the problems facing can be resolved.

Keywords - computerized, sales, design, system, uml, waterfall

\section{PENDAHULUAN}

Penjualan merupakan salah satu komponen yang penting dalam operasional sebuah perusahaan, sehingga perusahaan harus dapat memberikan pelayanan yang terbaik kepada pelanggan. Sistem penjualan adalah sistem yang melibatkan sumberdaya dalam suatu organisasi, 
prosedur, data, serta sarana pendukung untuk mengoperasikan sistem penjualan, sehingga menghasilkan informasi yang bermanfaat bagi pihak manajemen dalam pengambilan keputusan [1]. Salah satu teknologi yang memberikan kemudahan dalam kegiatan penjualan dan pengolahan data penjualan adalah menggunakan komputer, yang tentunya harus dilengkapi dengan program aplikasi tertentu. Pada saat ini, masih banyak organisasi atau perusahaan yang hanya mengutamakan peningkatan pendapatannya saja, tanpa memperhatikan bagaimana pengolahan datanya. Apakah data yang dihasilkan sudah akurat? Apakah laporan yang dibuat sudah sesuai dengan data yang ada? Apakah pimpinan dapat mengambil keputusan dengan segera dari laporan yang dihasilkan? Bagaimana penyimpanan datanya? Dan masih banyak pertanyaan yang lainnya.

Kalau hal ini tidak bisa dijawab oleh organisasi atau perusahaan dengan benar, maka usaha yang dilakukannya dalam meningkatkan pendapatannya akan mengalami banyak kendala. Bahkan merekapun dapat gulung tikar karena tidak memperhatikan bagaimana pengolahan datanya dengan benar dan kalah bersaing dengan organisasi atau perusahaan yang sudah menerapkan sistem yang lebih bagus dibanding sistem konvensional. Oleh karena itu, sangat penting sekali bagi organisasi atau perusahaan untuk mengembangkan sistemnya dari sistem konvensional menjadi sistem yang terkomputerisasi. Dengan adanya sistem komputerisasi tersebut diharapkan dapat menghasilkan data yang cepat dan informasi akurat sehingga dapat digunakan sebagai pengambilan keputusan oleh Pimpinan.

Toko Fadhil Genteng Bogor merupakan sebuah toko yang bergerak dibidang perdagangan, yang menjual berbagai macam bahan bangunan yang dapat digunakan untuk membangun ataupun merenovasi rumah atau bangunan yang lainnya. Berdasarkan hasil observasi yang telah dilakukan, diketahui bahwa sistem penjualan yang dilakukan di toko tersebut masih kurang efisien. Hal ini dikarenakan pengolahan data sistem penjualan masih menggunakan sistem konvensional, mulai dari proses pemesanan, proses pembayaran sampai dengan proses pembuatan laporannya sehingga banyak menimbulkan permasalahan. Menurut Stair dalam [2] mengatakan bahwa prinsip-prinsip sistem informasi dalam sebuah organisasi adalah penggunaan sistem informasi pada sebuah organisasi yang bertujuan untuk menambah nilai bagi organisasi tersebut sangat dipengaruhi oleh struktur organisasi, budaya dan perubahan.

Untuk mengatasi kendala ataupun permasalahan yang dihadapi pada Toko Fadhil Bogor ini diperlukan adanya pembangunan atau pengembangan terhadap sistem informasi penjualan yang berjalan pada saat ini. Hal ini bertujuan supaya sistem baru yang nantinya akan diterapkan dalam Toko Fadhil ini, bisa meningkatkan pelayanan yang baik kepada para pelanggan, meningkatkan kinerja dari pengolahan datanya serta bisa menghasilkan informasi yang dibutuhkan secara cepat dan akurat. Proses membangun perangkat lunak komputer dan sistem informasi selalu ditentukan oleh metodologi pengembangan yang berbeda. Metodologi pengembangan perangkat lunak dapat diartikan sebagai suatu proses membuat perangkat lunak baru atau hanya memperbaiki perangkat lunak yang sudah ada[3]. Oleh karena itu, diperlukan pemilihan metode atau model yang tepat dalam analisa, perancangan dan implementasinya sehingga dapat menghasilkan kinerja yang bagus dan bermanfaat.

Penerapan sebuah sistem, tidak hanya bergantung pada modelnya dan fitur-fitur dari perangkat lunak serta bahasa pemograman yang digunakan, akan tetapi harus memperhatikan model yang tepat untuk penerapannya sehingga apa yang menjadi tujuan utamanya bisa tercapai, menurut Britton dan Doake dalam [4]. SDLC atau Software Development Life Cycle atau sering disebut juga System Development Life Cycle adalah proses mengembangkan atau mengubah suatu sistem perangkat lunak dengan menggunakan model-model dan metodologi yang digunakan orang untuk mengembangkan sistem-sistem perangkat lunak sebelumnya (berdasarkan Best practice atau caracara yang sudah teruji dengan baik) [5]. Seperti halnya proses metamorphosis pada kupu-kupu, untuk menjadi kupu yang indah maka dibutuhkan beberapa tahap untuk dilalui, mulai dari tahap kepompong sampai menjadi kupu-kupu. Hal ini sama seperti dengan membuat perangkat lunak, memilih daur tahapan yang dilalui agar menghasilkan perangkat lunak yang berkualitas.

Ada beberapa metode SDLC seperti metode waterfall, metode prototype, metode RAD, metode iteratif dan metode spiral. Metode Waterfalldipilih sebagai alat bantu atau tools dalam rancang bangun sistem penjualan khususnya pada Toko Fadhil Genteng Bogor. UML (UnifiedModellingLanguage) adalah standarisasi internasional untuk notasi dalam bentuk grafik yang menjelaskan tentang analisis dan desain perangkat lunak yang dikembangkan dengan pemrograman berorientasi objek[6]. UML merupakan salah satu alat bantu yang handal di dunia perkembangan sistem berbasis objek, hal ini disebabkan karena UML menyediakan bahasa pemodelan visual yang memungkinkan bagi pengembang sistem untuk membuat cetak biru atas visi 
dalam bentuk yang baku, mudah dimengerti serta dilengkapi dengan mekanisme yang efektif untuk berbagi dan mengkomunikasikan rancangan dengan yang lain [1].

\section{METODE PENELITIAN}

Para peneliti dapat memilih berjenis-jenis metode dalam melaksanakan penelitiannya. Metode yang dipilihberhubungan erat dengan prosedur, alat, serta desain penelitian yang digunakan. Desain penelitian harus sesuai dengan metode penelitian yang dipilih. Prosedur serta alat yang digunakan dalam penelitian harus cocok dengan metode penelitian yang digunakan [7]. Jenis penelitian yang digunakan disini merupakan penelitian kualitatif dimana data yang diperoleh berdasarkan observasi dan wawancara serta didukung dengan penggunaan studi pustaka. Data-data yang diperoleh, nantinya akan digunakan dalam pengembangan sistem. Pengembangan sistem dapat berarti menyusun sistem yang baru untuk menggantikan sistem yang lama secara keseluruhan atau memperbaiki sistem yang sudah ada [8].Metode yang digunakan untuk pengembangan sistem adalah dengan metode SDLC, yaitu waterfall model.

Disebut dengan waterfall karena tahap demi tahap yang dilalui harus menunggu selesainya tahap sebelumnya dan berjalan berurutan, sebagai contoh tahap desain harus menunggu selesainya tahap sebelumnya yaitu tahap requirement [9]. Model air terjun (waterfall) menyediakan pendekatan alur hidup perangkat lunak secara sekuensial atau terurut dimulai dari analisis, desain, pengodean, pengujian, dan tahap pendukung (support)[5]. Berikut adalah gambar model air terjun :

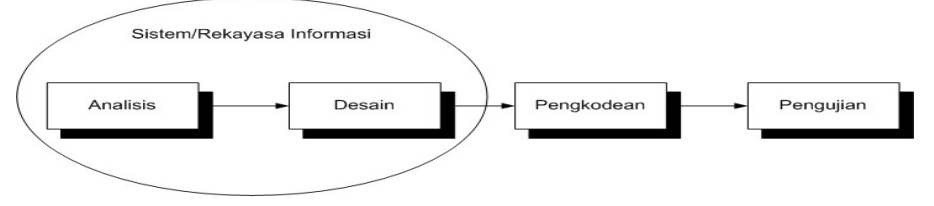

Gambar 1 Ilustrasi Model Waterfall

a. Analisis kebutuhan perangkat lunak

Proses pengumpulan kebutuhan dilakukan secara intensif untuk menspesifikasikan kebutuhan perangkat lunak agar dapat dipahami perangkat lunak seperti apa yang dibutuhkan oleh user.

b. Desain

Desain perangkat lunak adalah proses multi langkah yang fokus pada desain pembuatan program perangkat lunak termasuk struktur data, arsitektur perangkat lunak, representasiantarmuka, dan prosedur pengodean. Tahap ini mentranslasi kebutuhan perangkat lunakdari tahap analisis kebutuhan ke representasi desain agar dapat diimplementasikan menjadi program pada tahap selanjutnya.

c. Pembuatan kode program

Desain harus ditranslasikan ke dalam program perangkat lunak. Hasil dari tahap ini adalah program komputer sesuai dengan desain yang telah dibuat pada tahap desain.

d. Pengujian

Pengujian fokus kepada perangkat lunak secara logic dan fungsional dan memastikan bahwa semua bagian sudah diuji untuk meminimalisir error dan keluaran harus sesuai.Pemilihan cara pengujian dilakukan dengan menggunakan data-data yang sering digunakan untuk pengolahan data, mulai dari data opersional, data input dan output.

e. Pendukung (support) atau pemeliharaan (maintenance).

Dikarenakan adanya perubahan ketika sudah dikirimkan ke user. Perubahan dapat terjadi karena adanya kesalahan yang muncul dan tidak terdeteksi saat pengujian atau perangkat lunak harus beradaptasi dengan lingkungan baru. Tahap pendukung atau pemeliharaan dapat mengulangi proses pengembangan mulai dari analisis spesifikasi untuk perubahan perangkat lunak yang sudah ada, tapi tidak untuk membuat perangkat lunak yang baru.

\section{HASIL DAN PEMBAHASAN}

\section{Proses Bisnis}

Proses bisnis sistem penjualan tunai pada Toko Fadhil Genteng Bogor adalah : 
a.Proses pemesanan barang

Pelanggan melakukan pemesanan ke bagian penjualan maka bagian pejualan menerima pemesanan dan memeriksa barang, jika barang tidak ada bagian penjualan memberikan konfirmasi ke pelanggan. Jika barang ada maka dibuatkan nota, menyimpan nota pink dan menyerahkan nota putih ke pelanggan.

b.Proses pembayaran

Pelanggan melakukan pembayaran ke bagian penjualan maka bagian penjualan akan menerima pembayaran dan membuatkan surat jalan dan menyerahkan surat jalan ke bagian pengiriman.

c.Proses pengiriman

Bagian pengiriman menerima surat jalan dari bagian penjualan setelah itu bagian pengiriman akan menyerahkan barang dan surat jalan, Pelanggan akan menerima barang pesanan dan surat jalan, setelah pelanggan melakukan acc surat jalan, maka pelanggan akan menyerahkan surat jalan ke bagian pengiriman dan bagian pengiriman akan menerima acc surat jalan dan mengembalikan acc surat jalan tersebut kebagian penjualan.

d.Proses Pembuatan Laporan

Bagian penjualan akan membuatkan laporan penjualan dan menyerahkan laporan penjualan ke Kepala Toko.

Berikut penggambaran proses bisnis sistem penjualan dalam activity diagram :

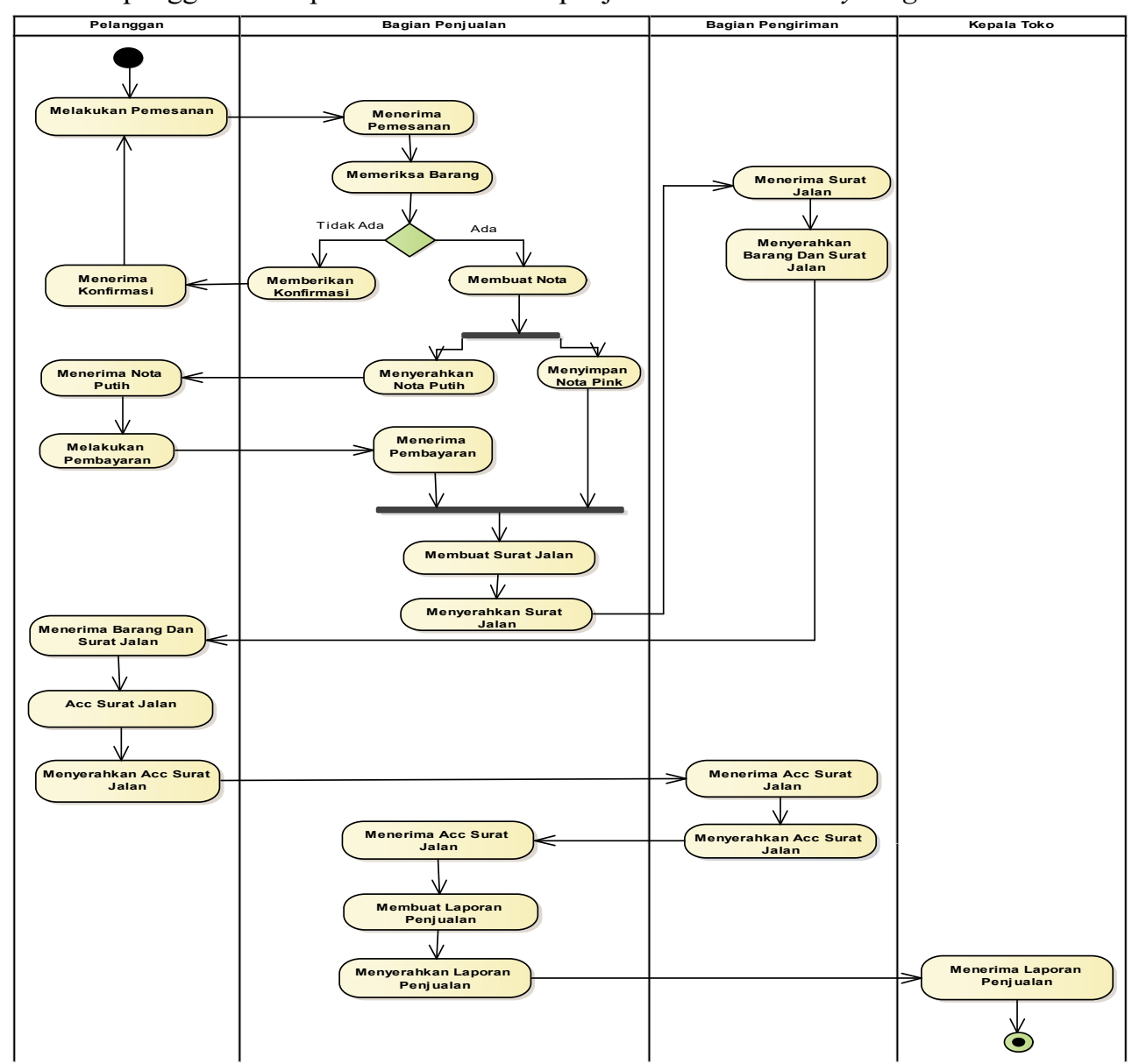

Gambar 2. Activity Diagram Sistem Berjalan

\section{a. Analisa}


Berdasarkan data-data yang diperoleh, maka dapat digambarkan mengenai analisa kebutuhan yang diperlukan dalam rancang bangun sistem penjualan, dalam hal ini pada Toko Fadhil Genteng Bogor ke dalam diagram Use case sebagai berikut :

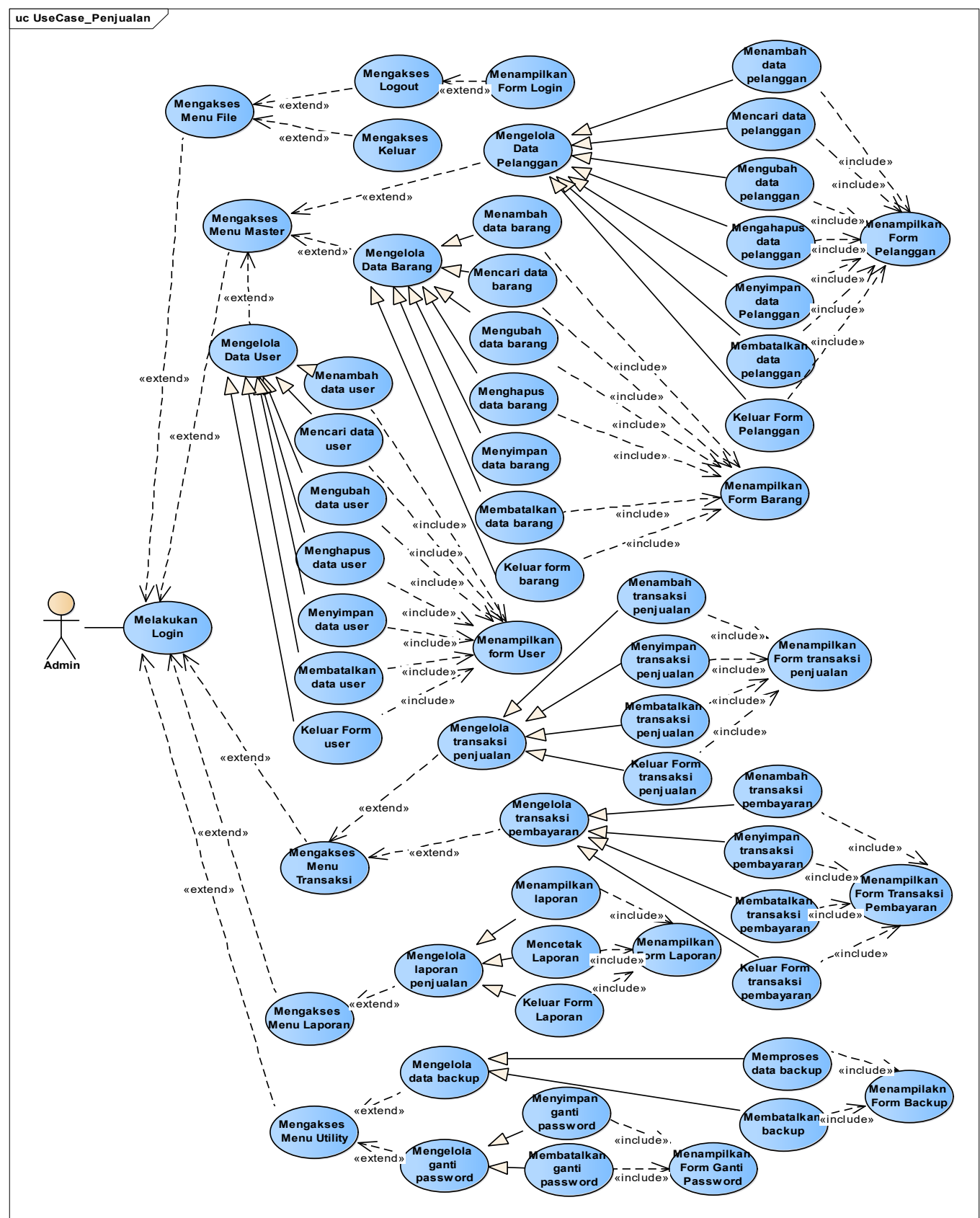

Gambar 3. Use case Diagram

\section{b. Desain}

1) Desain Database

Pembuatan desain database, diilustrasikan dalam bentuk ERD dan LRS. Adapun ERD dan LRS untuk rancang bangun sistem penjualan berdasarkan analisa kebutuhan yang telah ditentukan diatas, sebagai berikut: 


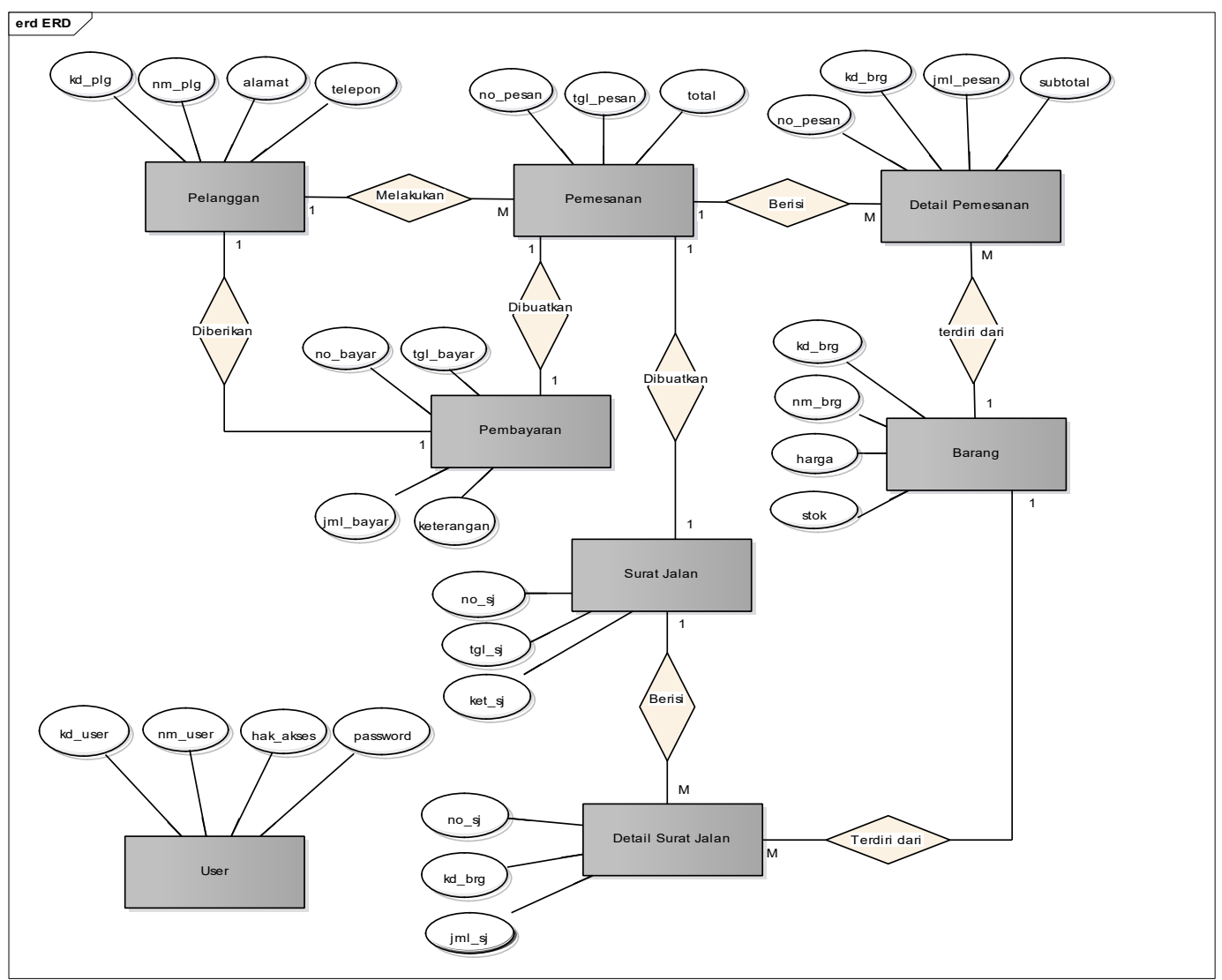

Gambar 4. ERD

Menurut Yasin dalam[4], ERD merupakan suatu bentuk hubungan kegiatan didalam sistem yang berkaitan langsung dan mempunyai fungsi didalam proses tersebut. Dalam ERD tersebut terdiri dari delapan entitas, yaitu entitas pelanggan, pemesanan, detail pemesanan, barang, pembayaran, surat jalan, detail surat jalan danuser. Entitas user ini, sebagai pengguna sistemnya.

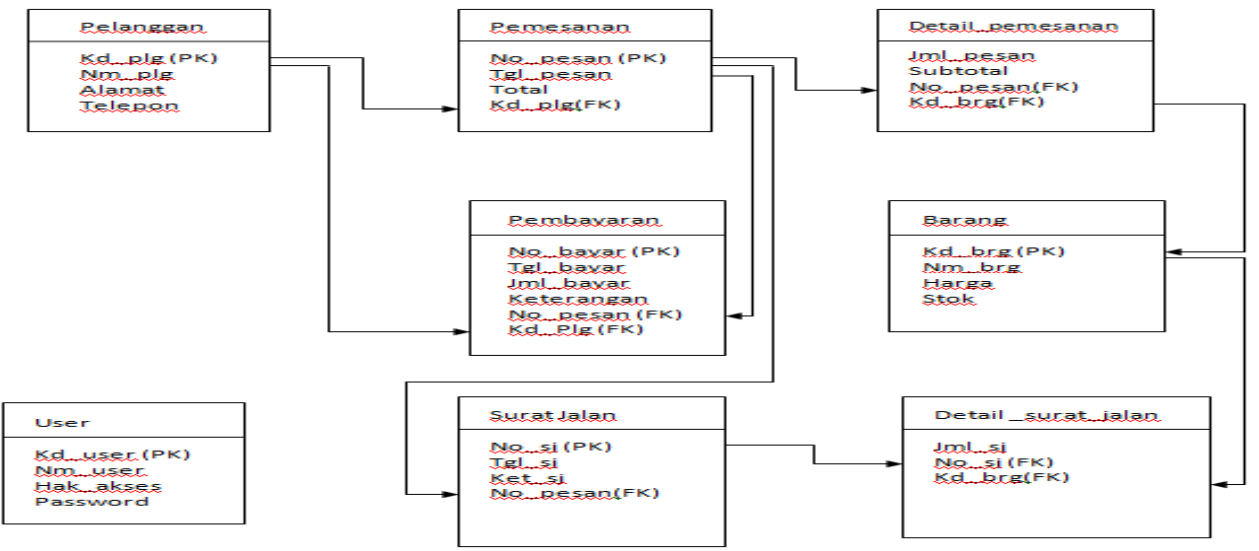

Gambar 5. LRS

LRS merupakan representasi dari pembuatan ERD, dimana setiap entitas dalam ERD akan berubah menjadi kotak atau tabel. LRS ini menggambarkan tabel-tabel yang digunakan dalam pembuatan aplikasi programnya. Setiap tabel terdiri dari atribut-atribut, yang sudah ditentukan primary key maupun foreign keynya.

\section{2) User Interface}




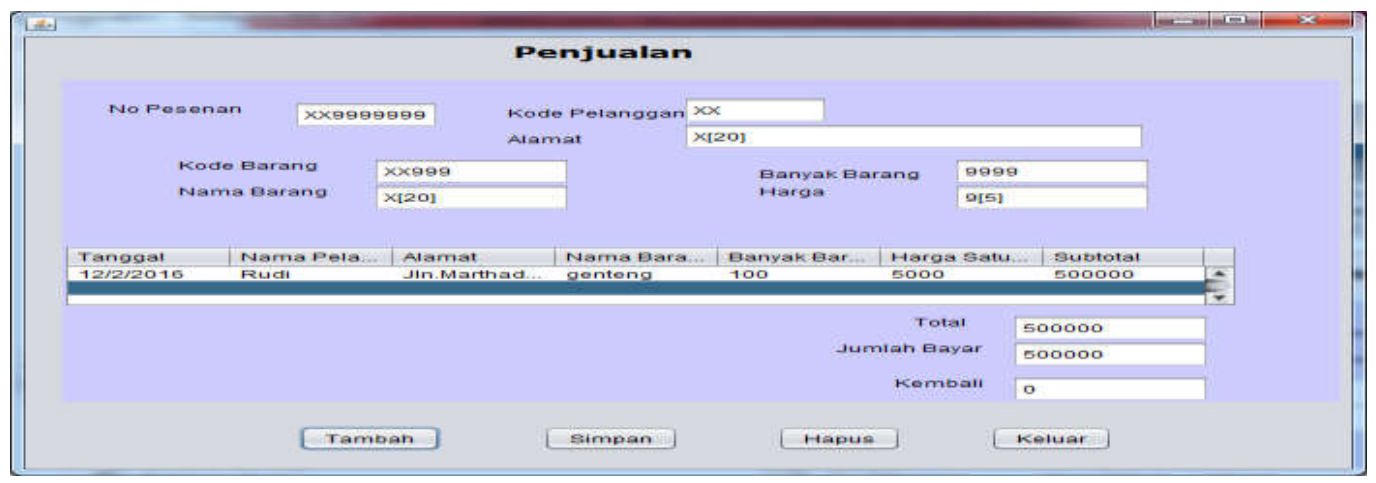

Gambar 6. Desain transaksi penjualan

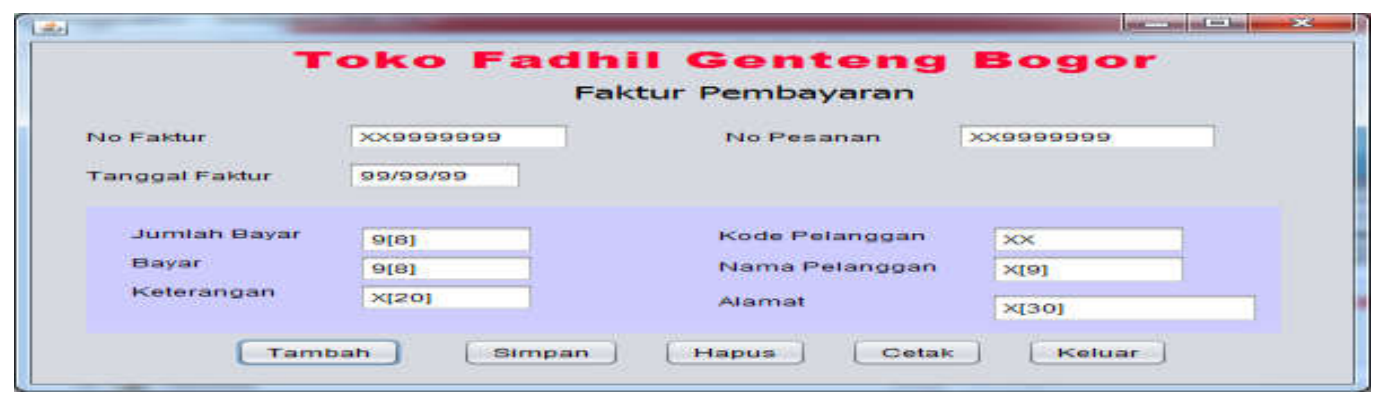

Gambar 7. Desain transaksi pembayaran

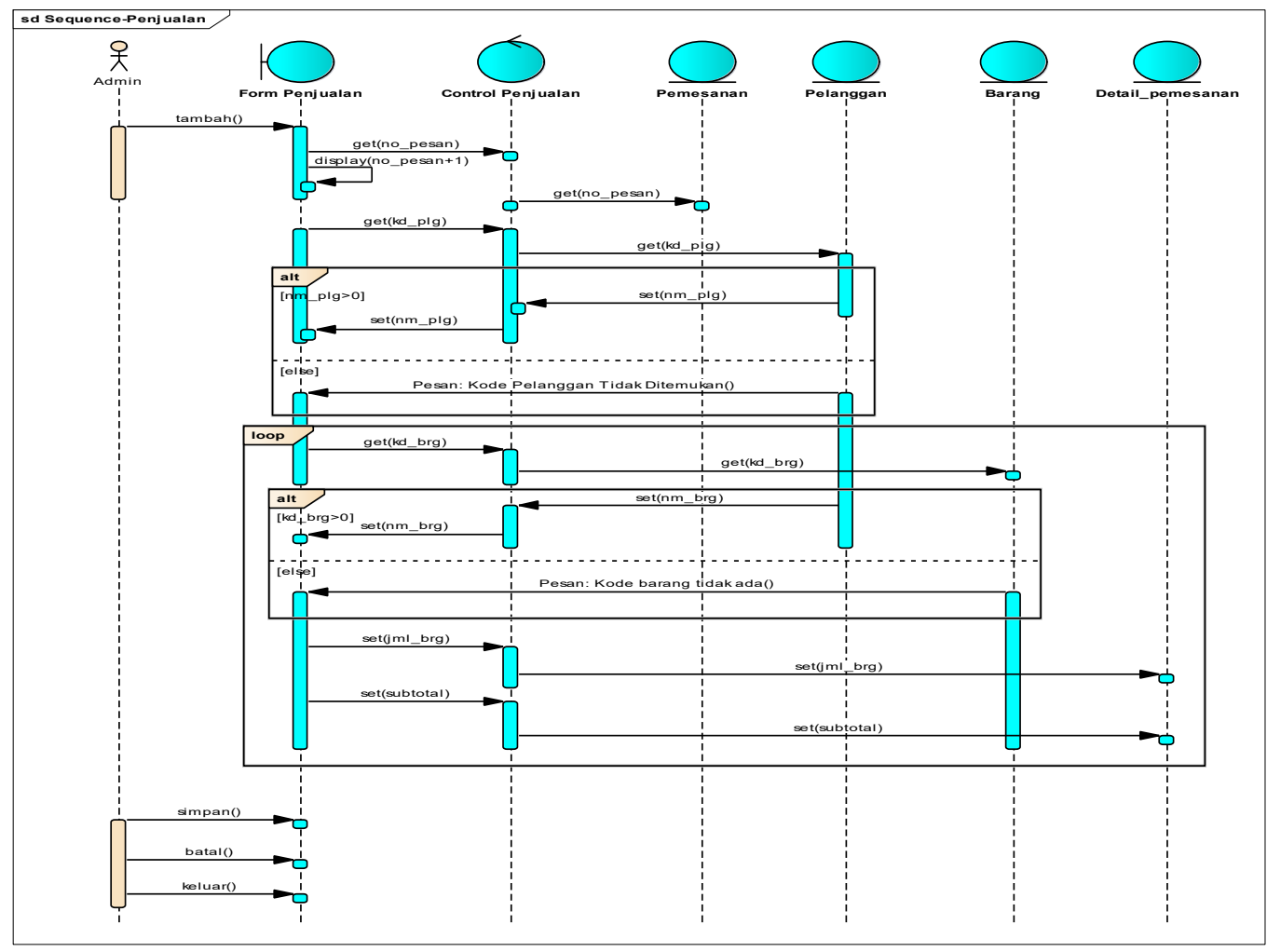

Gambar 8. Sequence Diagram Transaksi Penjualan 


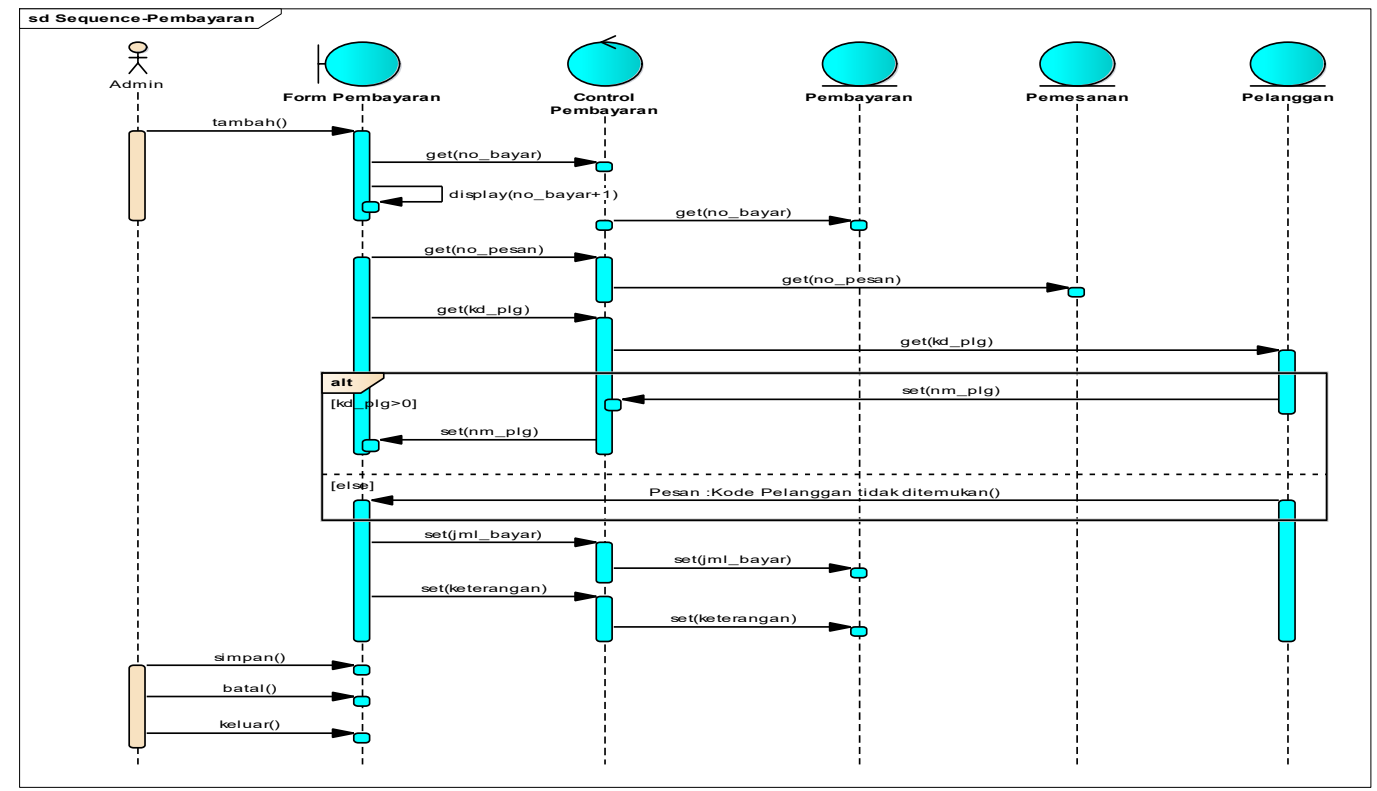

Gambar 9. Sequence Diagram Transaksi Pembayaran

\section{c. Pengkodean}

Dalam tahap ini dilakukan penulisan kode program dengan menggunakan bahasa pemrograman Netbeans dan MySQL untuk pembuatan databasenya. Adapun kode yang dibuat adalah Kode user, Kode barang, Kode pelanggan, Kode pemesanan, Kode pembayaran dan Kode surat jalan. Untuk dapat mengakses program aplikasi penjualan ini, diperlukan adanya login terlebih dahulu, agar keamanan data lebih terjamin. Sebagai contoh, listing program yang dibuat untuk Login, sebagai berikut :

package penjualan;

import java.sql. Connection;

import java.sql.DriverManager;

import java.sql.SQLException;

import java.sql.statement;

import java.sql.Resultset;

import javax.swing. JFrame;

import javax.swing. JoptionPane;

public class login extends javax.swing. JFrame \{

Connection con; Statement stm;Resultset rs;String sql;

public login() \{

initComponents(); setLocationRelativeTo(this); JFrame form=new

JFrame ();

form.setsize(400, 400); koneksi $D B=$ new koneksi ();DB.config();

con $=D B$. con; stm $=D B$.stm;

private void exitActionPerformed(java.awt.event. ActionEvent evt) \{ dispose(); this.setVisible(false);

this.setDefaultCloseOperation (EXIT_ON_CLOSE); System.exit (0);

private void btnloginActionPerforméd(java.awt.event. ActionEvent evt)

\{

aksi login();

public static void main(String args[]) \{

java.awt.EventQueue. invokeLater(new Runnable() \{

public void run() \{

new login(). setVisible (true);

\}\}; \}

private void aksi_login() (

String hak akses=aksesCB.getSelectedItem(). tostring();

if(username.getText().equals("") | | password.getText().equals("")) ( 


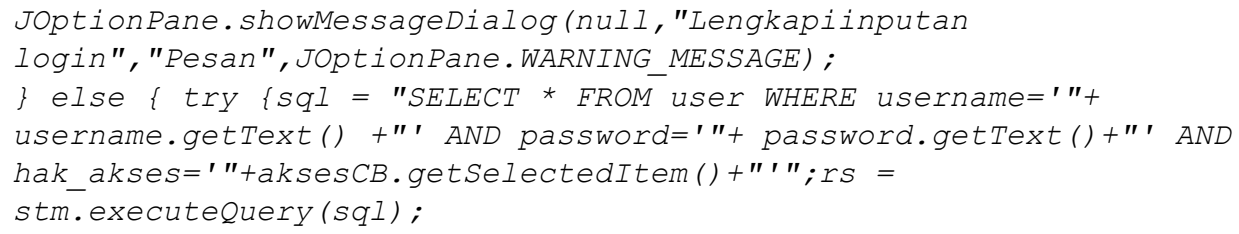

\section{d. Pengujian}

Setelah tahapan desain dan pengkodean telah selesai, maka dilakukan pengujian atau testing program untuk melihat apakah sudah sesuai dengan yang dibutuhkan baik mengenai input ataupun output yang dihasilkan, apakah masih ada kesalahan dalam programnya, sehingga nantinya aplikasi penjualan ini bisa diimplementasikan pada Toko Fadhil Genteng Bogor. Untuk lebih detailnya dalam pengujian ini menggunakan metode black box. Metode Black Box artinya menguji perangkat lunakdari segi spesifikasi fungsional tanpa menguji desain dankode program. Pengujian dimaksudkan untuk mengetahui fungsi-fungsi, masukan dan keluaran dari perangkat lunak sesuai dengan spesifikasi yang dibutuhkan. Berikut contoh hasil pengujian untuk Login :

Tabel 1. Hasil Pengujian Login

\begin{tabular}{|c|c|c|c|c|c|}
\hline No. & Skenario pengujian & Test case & $\begin{array}{l}\text { Hasil yang } \\
\text { diharapkan }\end{array}$ & Hasil pengujian & Kesimpulan \\
\hline 1. & $\begin{array}{l}\text { Hak akses, } \\
\text { Username dan } \\
\text { Password tidak diisi } \\
\text { kemudian klik } \\
\text { tombol login }\end{array}$ & $\begin{array}{l}\text { Hak Akses: } \\
\text { (Tidak dipilih) } \\
\text { Username: (kosong) } \\
\text { Password: (kosong) }\end{array}$ & $\begin{array}{l}\text { Sistem akan } \\
\text { menolak akses dan } \\
\text { menampilkan pesan } \\
\text { "Lengkapi Inputan } \\
\text { Login" }\end{array}$ & Sesuai harapan & Valid \\
\hline 2. & $\begin{array}{l}\text { Mengisi Hak akses, } \\
\text { Username dan } \\
\text { Password dengan } \\
\text { salah satu data yang } \\
\text { salah kemudian klik } \\
\text { tombol login }\end{array}$ & $\begin{array}{l}\text { Hak Akses: } \\
\text { Admin } \\
\text { Username: } \\
\text { ADM0101 } \\
\text { (benar) } \\
\text { Password: } 1234 \\
\text { (salah) }\end{array}$ & $\begin{array}{l}\text { Sistem akan } \\
\text { menolak akses dan } \\
\text { menampilkan pesan } \\
\text { "Maaf username } \\
\text { dan password yang } \\
\text { anda masukkan } \\
\text { salah" }\end{array}$ & Sesuai harapan & Valid \\
\hline 3. & $\begin{array}{l}\text { Mengisi Hak akses, } \\
\text { Username dan } \\
\text { Passworddengan } \\
\text { data yang benar } \\
\text { kemudian klik } \\
\text { tombol login }\end{array}$ & $\begin{array}{l}\text { Hak Akses: } \\
\text { Admin } \\
\text { Username: } \\
\text { ADM0101 } \\
\text { (benar) } \\
\text { Password: } \\
\text { P0101 } \\
\text { (benar) }\end{array}$ & $\begin{array}{l}\text { Sistem akan } \\
\text { menerima akses } \\
\text { login dan akan } \\
\text { menampilkan pesan } \\
\text { "Anda Berhasil } \\
\text { Login Sebagai } \\
\text { Admin". }\end{array}$ & $\begin{array}{c}\text { Sesuai } \\
\text { harapan }\end{array}$ & Valid \\
\hline
\end{tabular}

\section{e. Pendukung atau Perawatan}

Pada tahap ini, dilakukan perawatan sistemnya secara periodik dengan cara mengevaluasi dari sistem yang baru diimplentasikan. Apakah masih ada kekurangan atau kelemahan terhadap sistem barunya. Sehingga dari evaluasi ini diharapkan semakin memperbaiki kinerja dari sistem terutama pada sistem penjualan di Toko Fadhil Genteng Bogor.

\section{SIMPULAN}

Berdasarkan pemaparan diatas, maka dapat diambil kesimpulan sebagai berikut :

1. Penjualan merupakan salah satu komponen penting dalam organisasi atau perusahaan untuk dapat meningkatkan pendapatannya, sehingga diperlukan suatu sistem yang baik dalam pengolahan data-datanya. Sistem terkomputerisasi merupakan pilihan yang tepat untuk diterapkan dalam organisasi atau perusahaan dibanding dengan sistem konvensional. Banyak permasalahan yang timbul dengan masih digunakannya sistem konvensional, hal ini dapat mengakibatkan terganggunya kinerja organisasi atau perusahaan terutama dalam penjualan. Seperti yang dialami oleh Toko Fadhil Genteng Bogor. Toko tersebut membutuhkan adanya pengembangan sistem di dalam penjualannya. Dengan penggunaan sistem yang baru, diharapkan tujuan dari pengembangan sistem pada Toko tersebut dapat tercapai. 
2. Penggunaan sistem komputerisasi tentunya akan memberikan banyak manfaat bagi organisasi atau perusahaan, seperti pencarian data menjadi lebih mudah, informasi mengenai data-data yang diperlukan dapat dengan cepat didapatkan, penyimpanan data lebih terstruktur, dapat meminimalkan dalam kesalahan perhitungan, penyajian laporan dapat dengan cepat dan tepat waktu serta informasi yang dihasilkan lebih akurat. Sehingga pihak-pihak yang membutuhkan informasi berkaitan dengan kegiatan penjualannya dapat segera mendapatkannya dan nantinya dapat digunakan sebagai pengambilan keputusan.

3. Kekurangan dari penggunaan sistem komputerisasi ini adalah dibutuhkannya dana yang besar untuk membuat rancang bangun sistemnya. Organisasi atau perusahaan harus dapat mengalokasikan dana yang besar untuk menyewa seorang analis sistem beserta teamnya, mempersiapkan sarana dan prasarananya dari kebutuhan sistem barunya, dan siap memberikan pelatihan bagi karyawannya serta harus mampu memelihara sistemnya secara berkala.

4. Rancang bangun sistem penjualan ini dapat digambarkan dengan menggunakan diagram UML, sehingga dapat dilihat alur kerja sistem secara jelas dan kebutuhan-kebutuhan yang diperlukan oleh organisasi atau perusahaan. Seperti yang sudah digambarkan dengan activity diagram, use case diagram dan sequence diagram, dengan menggunakan contoh dari Toko Fadhil Genteng Bogor. Rancangan databasenya dapat dibuat dengan menggunakan ERD dan LRS.

\section{SARAN}

Berdasarkan hasil dan pembahasan tersebut, penelitian ini belumlah sempurna dan masih diperlukan kontribusi dari peneliti yang lainnya untuk dapat mengembangkan penulisan ini. Sehingga apa yang menjadi tujuan dan harapan dari penggunaan sistem komputerisasi benarbenar terealisasi dengan baik.

\section{DAFTAR PUSTAKA}

[1] Anggraini, Dina., Widiastuti, Faisal. 2013. Rancang Bangun Sistem Informasi dan Aplikasi Penjuala pada Koperasi Kartika Salak. Seminar Nasional \& Expo Teknik Elektro Ke-3 Tahun 2013. Banda Aceh. 26 Agustus 2013.

[2] Nurasiah. 2014. Perencanaan Pengembangan Sistem Informasi Pembayaran Uang Kuliah Dengan Metode SDLC Waterfall. Jurnal Teknologi dan Rekayasa. No.3. Vol 19. http://ejournal.gunadarma.ac.id/index.php/tekno/article/download/1112/973

[3] Bolung, Maikel,. Ronald, Henry., Tampangela, Karunia. 2017. Analisa Penggunaan Metodologi Pengembangan Perangkat Lunak. Jurnal ELTIKOM.No. 1. Vol. 1.2598-3288. http://eltikom.poliban.ac.id/index.php/eltikom/article/view/1

[4] Febriani, Annisa., Hidayati, Nur. 2017. Penerapan Aplikasi Program Penjualan Dan Pembelian Menggunakan Model Rapid Application Development. Jurnal Informatika. No. 2. Vol. 4. 23556579.https://ejournal.bsi.ac.id/ejurnal/index.php/ji/article/view/2206

[5] Sukamto, Ariani Rosa dan Shalahuddin, Muhamad. 2018. Rekayasa Perangkat Lunak Terstruktur Dan Berorientasi Objek. Informatika, Bandung.

[6] Pratama, I Putu Agus Eka. 2014. Sistem Informasi dan Implementasi Teori \& Konsep Sistem Informasi Disertai Berbagai Contoh Praktiknya Menggunakan Perangkat Lunak Open Source. Informatika, Bandung.

[7] Nazir, Muhamad. 2014. Metode Penelitian. Ghalia Indonesia, Bogor.

[8] Tohari,Himam. 2014. Analisis Serta Perancangan Sistem Informasi Melalui Pendekatan UML. Andi, Yogyakarta.

[9] Pascapraharastyan, Rizki Alfiasca., Supriyanto, Antok,. Sudarmaningtyas, Pantjawati,. 2014. Rancang Bangun Sistem Informasi Manajemen Arsip Rumah Sakit Bedah Surabaya Berbasis Web. Jurnal $\begin{array}{lllll}\text { Sistem Informasi. } & \text { No. } & 2 . & \text { Vol. } & 3 .\end{array}$ http:/jurnal.stikom.edu/index.php/jsika/article/view/289/228 